\title{
バイオマスエネルギーの活用からみた里山ゴルフ場の役割
}

\section{Ecological Potential of Golf Courses on Satoyama Hills for Biomass Energy Utilization}

\author{
安田信太郎* 横張 真** \\ Shintaro YASUDA, Makoto YOKOHARI
}

\begin{abstract}
摘要：里山管理から発生する植物性廃棄物をエネルギー資源として有効利用することは，二酸化炭素 の排出量削減に向けた取り組みとして意義がある。本研究では，里山ゴルフ場から発生する刈り芝残 さに着目し，その発生量を実測にもとづき推定した。5 種の芝タイプにおける調査から，乾物量換算 で年間 $398 \mathrm{~g} / \mathrm{m}^{2}$ の刈り芝残さが調查対象ゴルフ場の管理芝地から発生していると推定した。また, ガス化・メタノール製造法により，398 g の刈り芝残さから $175 \mathrm{~g}$ のメタールが得られると推定した。 さらに, より多くのエネルギーを得るための里山ゴルフ場の管理・誘導指針を, 刈り芝残さの回収量 の増加および刈高の変更から示した。
\end{abstract}

\section{1. はじめに}

「エネルギーとして利用できる植物資源 11 之一般に定義され るバイオマスの利用は，これまでの大規模供給を主眼とする資源 利用体系に扔いては，発生源が広範囲に点在するために，コス卜 的に見合わないとされてきた。しかし，温暖化対策の目的財源之 して温暖化対策税の導入が検討されていることに見られるように， 経済システムは環境保全に向けて見直されてきている2”。現行の 資源利用体系に抢いて経済的価值をむたないとされる資源であっ ても，環境保全に向けた新たな資源利用体系の構築により，有効 利用が推進されてくると考えられる。

バイオマス供給の中心となる可能性のある地域のひとつとして 里山がある。ここでいう里山は，薪炭林や農用林などの二次林に 加え，草地や柴地までを含めた，人為的な影響のもとで形成され 管理されてきた緑被地をさす。薪や木炭などの需要低下に伴い管 理放棄が進行した里山であるが，環境への負荷の小さい新エネル ギーの供給源として新たに価値が生じると考えられる。

バイオマスエネルギーの導入において, 最む供給可能性が高く 現実的な利用が見込まれる原料は廃棄物系バイオマスである ${ }^{12 。}$ 里山の廃棄物系バイオマスとしては植生管理から発生する植物性 廃棄物がある。なかでも里山に数多く立地するゴルフ場（以下， 里山ゴルフ場とする）から発生する刈り芝残さは，主要な廃棄物 系バイオマスである。集約的なコース管理から発生する刈り芝残 さは，モア（刈芝機）による刈り込みにより，すでに粉砕された 状態で発生し，無用な廃葉物として多くが回収，処分されている。 回収や粗砕に新たなコストが生じる林地残材や農業残さなどと異 なり，導入が容易なバイオマスであるといえる。また，污泥や生 ごみなどと同様に，すでに普及が進んでいるコンポスト化装置や 炭化装置などでの処理が可能であるとともに，植物性廃棄物とし て，発酵法によるエ夕ノール製造，ガス化による液体燃料製造な どのエネルギー原料とすることができる。化石燃料代替のバイオ マスエネルギーとして，その有効活用を検討することは，二酸化 炭素の排出量削減に向けた取り組みとして意義をむつ。

ゴルフ場刈り芝残さをバイオマスエネルギー源として利用する ためには，まずその発生量を正確に把握する必要がある。それに より, 得られるエネルギー量やコストの推定, 採算性の検討, エ ネルギー活用に向けた段階的な取り組み案の策定など，一連の作 業が可能になる。そこで本研究では，ゴルフ場刈り芝残さの発生
量を，実測にもとづき把握した。また，㺫り芝残さから得られる エネルギー量を推定した。さらに，より多くのエネルギーを刈り 芝残さから得るための管理誘導指針を示し, 里山ゴルフ場におけ るバイオマスエネルギーの活用を展望した。

\section{2. 研究の方法}

\section{(1) 調查対象の概要}

調查対象は，埼玉県比企北丘陵内に位置するAゴルフ場（1995 年開場）とした。約 3,300ha の比企北丘陵内（図-1）には, A ゴルフ場を含む 5 つのゴルフ場（513ha）が開場するほか, 国営 武蔵丘陵森林公園（304ha）が開園している。この地域は, 標高 $100 \mathrm{~m}$ 前後のなだらかな丘陵地と多くの谷津を含む里山地域であ り, 戦後には, 茅場, 芝地, 薪炭林など, さまざまな緑被地が空 間的にも時間的にもモザイク状に分布していだ”。

A ゴルフ場は, 167ha の総面積に 87ha の管理芝地を含み, 27 ホールを有するゴルフ場である。管理芝地面積は丘陵内最大であ り, 平坦なプレーゾーンをむつ。特に限られた時間の中で, 芝地 管理抢よびプレーに配慮しながら実施しなければならない検体の 回収に有利であると考え，Aゴルフ場を調査対象として選定した。 また， 2 グリーンを有し， 2 種のグリーンに関する調査が可能で あったことも選定理由である。管理芝地の内訳は表一 1 の通りで ある。刈り込み管理から発生した刈り芝バイオマスは, 重油を補 助燃料とし, 焼却処分の対象となってきた。しかし, 廃棄物処理 法の改正に伴う野焼きの禁止により，2000 年以降はゴルフ場敷 地内において投棄処分されている。投棄処分用地をゴルフ場敷地 内に継続的に確保することが困難なため, 適切な処理法の導入が 求められている。

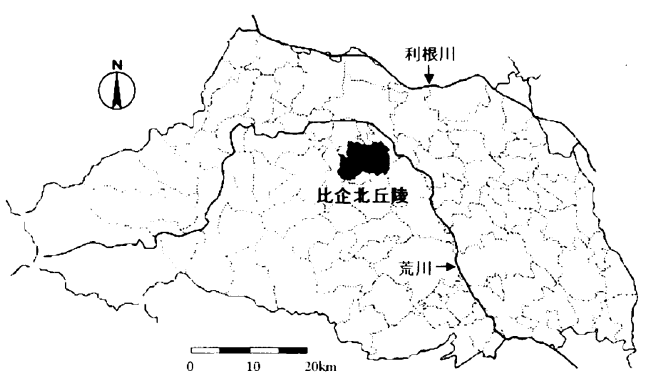

図ー1 A ゴルフ場が立地する比企北丘陵地域

*筑波大学大学院環境科学研究科 * 筑波大学社会工学系 
表ー1 A ゴルフ場における芝刈り込み状況（2000 年度）

\begin{tabular}{c|c|c|c|c}
\hline & 面積(ha) & 年間刈込回数 & 刈込時期 & 刈高 $(\mathrm{mm})$ \\
\hline ベントグリーン & 2.2 & 260 & 通年 & 4.0 \\
ティフトングリーン & 1.7 & 95 & 4月〜11月 & 4.0 \\
洋芝ティー & 1.6 & 55 & 3月 1月 & 10.0 \\
ティフトン高麗ティー & 1.1 & 23 & 4月 11月 & 10.0 \\
フェアウェイ & 22.1 & 21 & 5月〜10月 & 15.0 \\
ラフ & 57.9 & 16 & 5月〜10月 & 40.0 \\
\hline
\end{tabular}

（2）刈り芝残さ発生量の推定

調査対象とした芝タイプについて 1 年を通したデータが得られ るまで, 2000 年 7 月から 2001 年 9 月にかけてAゴルフ場で刈り 芝残さを回収した。回収された刈り芝残さの一部を $80^{\circ} \mathrm{C}$ の乾燥 器で 3 日間乾燥させた後, 乾燥重量を測定した。推定された単位 面積あたりの刈り芝残さの発生量を, 前回刈り込みからの経過日 数で除することにより，1日あたりの発生量を把握した。なお， 耕転作業後掞よびサッチ予防のためのバーチカルモア（密接した 鉛直ブレードをもち，横に延びた芝を切断除去することで芝密度 を低下させる特殊モア）の使用時に回収された検体，および目砂 が少しでも混入した検体は無効とした。調査日数合計, 無効とさ れた検体を除く有効検体数, および前回刈り込みからの平均経過 日数は表- 2 の通りである。刚り芝残さの回収方法は, 芝タイプ ごとの刈り込み管理仕様の違いに応じて, 以下のとおりとした。

(i) グリーン

クリーピングベントグラス（Agrostis palustris）を使用する ベントグリーンと，バミューダグラス（Cymodom dactylon）を 使用するティフトングリーンの 2 種がある。グリーンでは精密な 刈り込みと完全な刈り芝残さの除去が要求されるため, 刈り込み 之回収を同時に抢こなうモアが使用されている。刈り芝残さの発 生量に応じて, 1 〜 ホール程度のグリーンの刈り込みが連続し ておこなわれ，モ乃付属のバスケットに刈り芝残さが回収されて いる。そのバスケット内の刚り芝残さ全てをプラスチックバッグ に移し，測定対象とした。生草重量を測定したのち，300 g 500 $\mathrm{g}$ 程度を抜き取り, 乾物量を求める検体とした。推定乾物量およ び A ゴルフ場諸元一覧に記載されたグリーンの面積から，単位 面積あたりの刈り芝残さ発生量を推定した。

(ii) ティー

ケンタッキーブルーグラス（Poa pratensis）を使用する洋芝 ティーと，バミューダグラスと高麗シバ（Zoysia matrella）を 混合使用するティフトン・高麗ティーがある。主に洋芝ティーが プレーに使用され，芝の張り換えや残暑期の生育の衰えに対する 措置として，ティフトン・高麗ティーが使用される。そのため, 刈り込み回数は洋芝ティーが年 55 回であるのに対し，ティフト ン・高麗ティーは年 23 回である（表一 1 )。ティフトン・高麗ティー は刈り込み頻度が低く，ティー上での調査区の設置も不可能であっ たため, 洋芝ティーにおける推定乾物量をむって, ティーの刈り 芝バイオマスとした。Aゴルフ場内の総芝地面積に対するティフ トン・高麗ティ一面積は約 $1.3 \%$ にどまっており，ゴルフ場全 体の刈り芝バイオマスの推定における影響はほぼないものと考え られる。グリーンと同様, 刈り込みには刈り込みと回収を同時に おこなうモアが使用されており，回収およびバイオマス推定方法 はグリーンと同一である。

(iii）フェアウェイ

フェアウェイでは, 高麗シバが使用されている。刈り込み上回 収は別々におこなわれている。大型の乗用モアにより刈り込みが おこなわれ, 放置された刈り芝残さはスィーパーにより適宜除去 される。刈り込み前後に $1 \mathrm{~m} \times 1 \mathrm{~m}$ の調查区をフェアウェイ中央 部の平らで芝生がえぐられていない場所に一時的に設け, 刈り芝 残さを回収した。刈り込み前にも回収をおこなう理由は，前回の 刈り込みで発生した刈り芝残さがスィーパーでは完全に除去され
表ー2 A ゴルフ場における現地調査概要

\begin{tabular}{c|c|c|c}
\hline & 調査日数合計 & 有効検体数 & 平均経過日数 \\
\hline デントグリーン & 19 & 47 & 1.3 \\
ティトトグリーン & 11 & 35 & 1.8 \\
ティー & 12 & 29 & 6.3 \\
フェアウェイ & 9 & 61 & 11.4 \\
ラフ & 15 & 127 & 13.7 \\
\hline
\end{tabular}

ることがなく, 刈り込み後に回収される刚り芝残さに混入するか らである。刈り込み前後の乾物量の差を算出し, その地点での刚 り芝残さ発生量とした。なお，2つの隣接した調査区を設けるこ とができた場合には, それらの乾物量の平均值をその地点での測 定值とした。調查日数合計はフェアウェイの刚り込みに立ち会う ことができた 9 日であり, 調查地点述べ数は 24 であった。 24 調 査地点のうち, 刈り込み前後共に隣接調査区を設けることができ たのは 6 地点であり，刈り込み前あるいは刈り込み後のいずれか に隣接調査区を設けることができたのは 7 地点である。残りの 11 地点は単調査区のみを設けた。なお, 回収にはペット用ブラ シと携帯掃除機を使用した。フェアウェイは, モアの進入前後に 調査区を設け，進入前後に回収された刈り芝残さ発生量の差をむっ て, その地点での刈り芝残さ発生量としたので, 図一 5 に示され た実測值の数は表 -2 に示された有効検体数とは異なる。表 -2 の有効検体数 61 に対し, 図- 5 に示された実測值の数は 24 である。 (iv) ラフ

ラフには, ノシバ (Zoysia japonica) が使用されている。フェ アウェイ同様, モアによる回収とスィーパーによる刈り芝残さの 回収が別々におこなわれている。しかし，刈高が $40 \mathrm{~mm}$ と他の芝 タイプに比べて高く, 刈り込み回数む年間 16 回と他の芝タイプ に比べて少ないため, フェアウェイ同様の手法による刈り芝残さ 発生量の推定では, 推定精度は極めて低くなる。そこで, 調查目 的の刚り込みによる刈り芝残さ発生量の推定をおこなった。刚り 込みには, 実際のコース管理における刈り込み高に等しい $40 \mathrm{~mm}$ の高さをもつ $0.100 \mathrm{~m}^{2}$ の正方形の枠と芝刈り鋏を用いた（図－2）。 調查枠上面には $5 \mathrm{~cm}$ おきにテグスが張られ，これより上部にはみ 出した芝草を刈り取り, 乾燥重量を求めた。

しかし，50ha を超える広大なラフを，刈り込み調査のみで把 握することには限界がある。そこで, 草丈と刈り芝の乾燥重量の 回帰式を求め, 草高から乾燥重量を推定することにより, 刈取り 調查を補足した。草高は藤崎式芝生草高計を用いて測定した（図一 $3)^{4)}$ 。隣接した 5 箇所でこの草高計により計測された草高の平 均値をむって, その地点での草高とした。回帰式は $0.1 \%$ 水準で 有意であり, 草高による刈り芝発生量の推定は十分に有効之考え られた（図一 4)。ラフの調査区は，日射を遮る樹木の周りおよ び過度の水分が供給される斜面下部の排水栘の周辺を避けて A ラ フ（傾斜角 10 度以下かつ樹林間隔が $5 \mathrm{~m}$ 以上の芝地）上に設置 した。また，50ヤード以上の間隔を保ち，限られた調査時間内 でなるべくコース全体を網羅できるように設置した。総検体数は 127 であるが，96 検体は草丈から間接的に求められたものである。
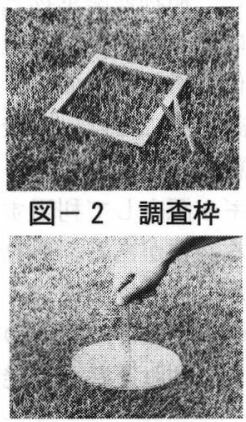

図-3 草高計

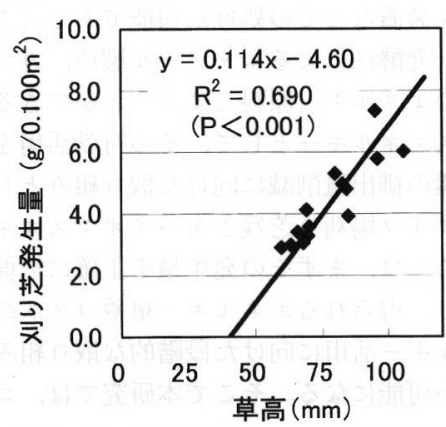
芝発生量の回帰直線
図ー4ラフにおける草高と刈り 

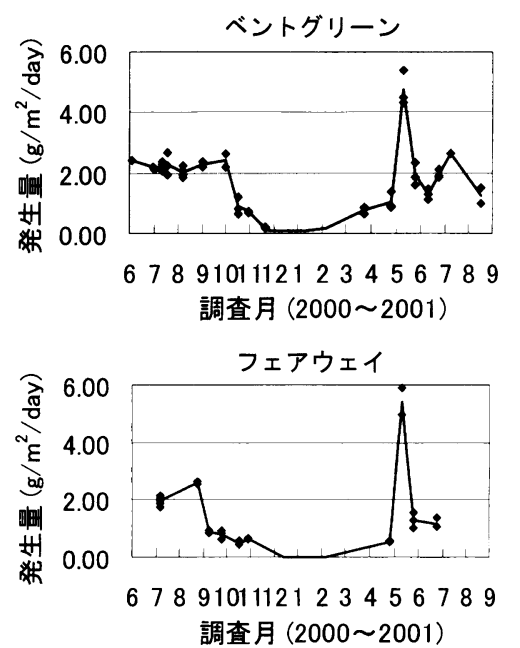

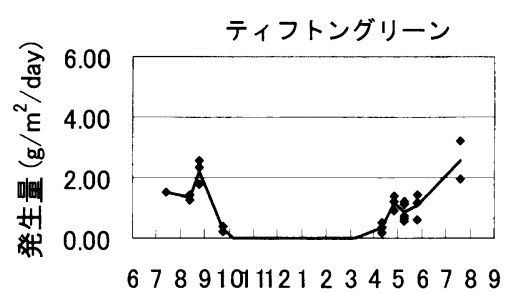

調查月 $(2000 \sim 2001)$

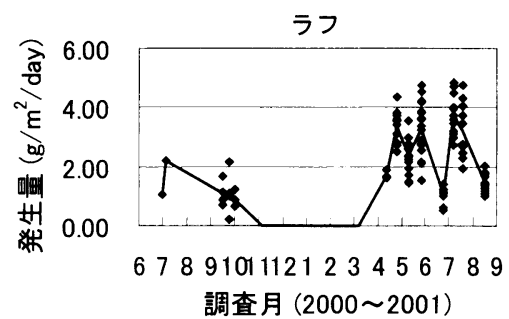

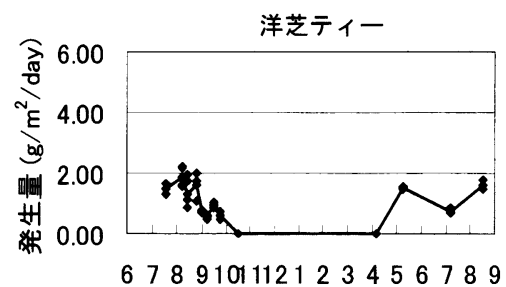

調査月 $(2000 \sim 2001)$

全管理芝地平均

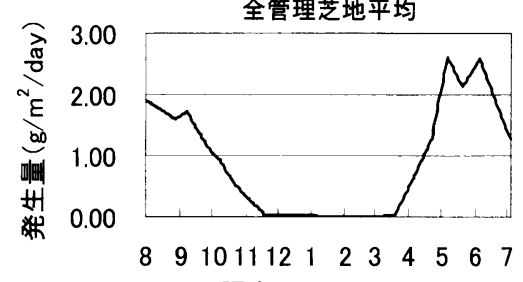

調查月 $(2000 \sim 2001)$

図ー5 刈り芝残さ発生量の年間推移（単位面積あたり1日）

\section{3. 研究の結果}

それぞれの芝タイプにおける単位面積あたり 1 日の刈り芝残さ 発生量の年間推移を図ー 5 に示す。网中の点は実測值を示し, 実 線は平均值の推移を示す。な招, 冬季中の刈り込み作業の休止期 については，刚り芝残さの発生量をゼロとした。

すべての芝タイプに共通の傾向として, 春季に刈り芝残さ発生 量が増加し，夏季から冬季にかけて減少することが羿められた。 全管理芝地平均での単位面積あたり刈り芝残さ発生量の年間推移 を, 芝タイプ別の刚り芝残さ発生量に各管理芝地面積を乗じ, そ れらの合計を総管理芝地面積で除することから得た（図一 5 )。 調査日あたりの測定結果におけるバラッキは, 日照条件および傾 斜や潅水などによる水分条件の違いによるもの上考えられる。

また, 刈り芝残さ年間推定発生量を, 1 日の平均刈り芝残さ発 生量に年間日数 365 を乗ずることから得た。表一 3 がその結果で ある。な技,ここでいう 1 日の平均刚り芝残さ発生量之は, 四一 5 に示される刈り芝残さ発生量の年間推移を積分したものを各芝 タイプ別の調查期間内日数で除したものである。

以上より A ゴルフ場全体では, 年間約 $345 \mathrm{t}$ の刈り芝残さが発 生していると推定した。このA ゴルフ場全体の年間発生量を総芝 地面積で除し, 単位面積あたりでは, 年間 $398 \mathrm{~g} / \mathrm{m}^{2}$ の刈り芝残 さがゴルフ場の管理芝地から発生していると推定した。刈り芝残 さ発生量をより正確に把握するためには, 刈り込み作業日数に対 する調查日数や調査日あたりの検体数の不足による䛊差, 抢よび 発生量の年次变動なよ゙を踏まえた調査がさらに必要である。他の ゴルフ場でも, 使用されている芝の種類および刈高なよ゙に大きな 違いはない上されるがう, 推定值に一般性をもたせるためには, 本研究之同樣の視点で他のゴルフ場にもアプローチ寸る必要がある。

\section{4. 考察}

単位面積あたりの年間刈り芝残さ発生量には, 芝タイプ別に相 違が認められた。この要因としては, 施肥量, 潅水回数, および 刚高などの違いが考えられる。実際に, 施肥量および潅水回数の 多いベントグリーン扰よ゙゙ティーでは, 単位面積あたりの年間刈 り芝残さ発生量がティフトングリーンやフェアウェイに比べ, 多 くなっている(表一 3 )。

一方, 刚高は, 芝草の LAI（葉面積指数）に影響を与える。大 きい LAI は, 光合成量の増加につながり, 生長量を増大させる。 施肥量が少なく, 潅水回数が低いにもかかわらず, ラフの単位面 積あたり年間刈り芝発生量が多いのは, 他の芝夕イプに比べて刈 高が特に高いことによるものと考えられる（表－1 および表－4）。
表一 3 刈り芝残さ年間推定発生量

\begin{tabular}{|c|c|c|c|c|c|c|}
\hline & \multicolumn{3}{|c|}{ 単位面積あたり $\left(\mathrm{g} / \mathrm{m}^{2}\right)$} & \multicolumn{3}{|c|}{ Aゴルフ場全体( $t / 87 \mathrm{ha})$} \\
\hline ベントグリーン & \multicolumn{3}{|c|}{\begin{tabular}{|c|}
522 \\
\end{tabular}} & \multicolumn{3}{|c|}{12} \\
\hline ティフトングリーン & \multicolumn{3}{|c|}{214} & \multicolumn{3}{|c|}{4} \\
\hline ティー & \multicolumn{3}{|c|}{358} & \multicolumn{3}{|c|}{10} \\
\hline フェアウェイ & \multicolumn{3}{|c|}{248} & \multicolumn{3}{|c|}{55} \\
\hline ラフ & \multicolumn{3}{|c|}{458} & \multicolumn{3}{|c|}{265} \\
\hline & \multicolumn{3}{|c|}{ (平均 $398 \mathrm{~g} / \mathrm{m}^{2}$ ) } & \multicolumn{3}{|c|}{ （合計 345t) } \\
\hline \multirow[t]{3}{*}{ 表 -4} & \multicolumn{6}{|c|}{ コース管理実績（2000 年度） } \\
\hline & \multirow{2}{*}{ 施肥回数 } & \multicolumn{3}{|c|}{ 施肥量 $\left(\mathrm{g} / \mathrm{m}^{2}\right)$} & \multicolumn{2}{|c|}{ 作業回数 } \\
\hline & & $\mathrm{N}$ & $\mathrm{P}$ & $\mathrm{K}$ & 目土 & 潅水 \\
\hline ベントグリーン & 24 & 25.0 & 19.6 & 39.6 & 8 & 55 \\
\hline ティフトングリーン & 7 & 5.7 & 4.1 & 5.8 & 2 & 6 \\
\hline 洋芝ティー & 13 & 21.4 & 19.3 & 22.0 & 4 & 29 \\
\hline フェアウェイ & 3 & 11.0 & 11.0 & 11.0 & 0 & 4 \\
\hline ラフ & 2 & 5.2 & 5.2 & 5.2 & 0 & 0 \\
\hline
\end{tabular}

5. 刈り芝残さから得られるエネルギー量の推定

里山ゴルフ場では, 刈り芝残さに加え, 樹木剪定や樹林地管理 からもさまざまな植物性廃衰物が発生している。そこで, あらゆ る植物性廃衰物を原料とできる，ガス化・メ夕ノール製造法 ${ }^{6) を ~}$ 用いた場合の刚り芝残さの活用に向けた検討をここではおこなう。 ソルガム茥葉部をこの製造法の原料とした際, 対バイオマス乾物 重の低位発熱量（実際に装置を動かした場合に得ら机る発熱量） で $15.15 \mathrm{MJ} / \mathrm{kg}$, メ夕ノール重量収率（原料に対するメ夕ノール 生産重量の比率）で44\%の值が報告されている7。メ夕ノール 重量收率は, 炭素含量が 48.3 51.1\% と高い米糠や杉木紛で 55 〜 56\%の高い值が, 炭素含量が 36.9 40.0\%上低い稲真や籾款で 36〜39\%の低い值が確認されている。刈り芝残さの炭素含量は高 麗シバで $42.1 \%$, ベントグラスで $46.5 \%$ など ${ }^{8}$, ソルガム茥葉 部の炭素含量 $44.4 \%$ に近い值を示している。そのため, ソルガ ム茥葉部のメ夕ノール重量收率を刈り芝残さに適用した。その結 果, ゴルフ場管理芝地における $1 \mathrm{~m}^{2}$ たりの年間刈り芝発生量 $398 \mathrm{~g}$ （表一3）からは, 理論值で $175 \mathrm{~g}$ のメノール（6.03MJ 相当）が得られると推定された。メタノールは燃料電池車やアル コールエンジン車の燃料として利用することができる。次世代の ゴルフカート，モア，および他のコース管理用車両などの燃料之 して有望視される。

メ夕ノール製造の排気処理段階においては, 副生物として粉末 状の硝安, 硫安を生成できる電子ビーム排煙処理技術 ${ }^{9}$ なよ゙を導 入し，肥料の生産を同時に進めるべきであろう（図-6）。刚り 芝残さ由来の肥料を化学合成肥料に代替させることは, 化学合成 肥料の製造や運搬におけるエネルギー消費を節減することになる。 刈り芝残さの直接的なエネルギー利用之同様に, 二酸化炭素の排 


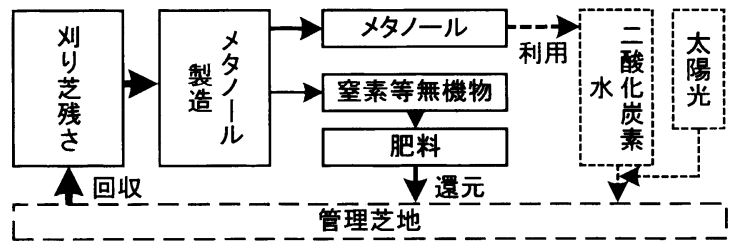

図一6 刈り芝残さのエネルギー活用体系

出量削減に向けた取り組みとして意義をもつ。

\section{6.ゴルフ場の管理・誘導指針}

刚り芝残さのエネルギー活用に向けては，プレーへの配慮とコー ス管理との兼和合いが重要である。現状で既に回収されている刈 り芝残さの活用からはじめ, 無理のない範囲で, 段階的により多 くのエネルギーを得るための取り組みに着手するべきであろう。

より多くのエネルギーを得るには, 現状で全回収されていない フェアウェイ拉よびラフの刚り芝残さを少しでも多く回収するこ とと, 刈り芝残さの発生量自体を增やすことが有効である。ただ し，刈り芝残さ回収の際には，芝草が土壌から吸収した養分を補 い, 地力を維持するために, 回収した刈り芝残さが含む養分を芝 生地に還元する必要がある。さきに述べた刈り芝残さ由来の肥料 を活用するべきであろう。また，さらなる回収には新たなコスト が生じるが，刈り芝残さから得られる燃料や肥料の導入により製 品の購入を削減できることから, 消却できると考えられる。

刈り芝残さの発生量自体を増やすためには，刈高を高くするこ とにより LAI を増加させ, 芝草の生長を高めることが有効であ る。とくに, 管理芝地面積の約 $2 / 3$ を占めるラフの生長を高め ることにより，ゴルフ場全体の刚り芝残さ発生量を効果的に増加 させることができる。このことは二酸化炭素固定量を増加させる 取り組みとしても意義がある。2001 年 9 月に，Aラフのうち, 日中に陰とならない中間的な草勢をむつ場所の 5 地点から得た検

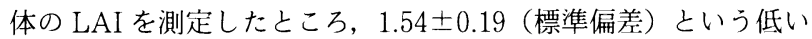
值が得られた。現状のコース管理では，ラフが一様に $40 \mathrm{~mm}$ で刈 り込まれており，全体的にLAI の増加が制約を受けていると考 えられる。

フェアウェイに近いラフでは, プレーの円滑な進行をはかるた め，刈高を高くすることは難しい。しかし，ゴルフボールがあま り飛んでいくことのないフェアウェイから離机たラフでは，刚高 を高くすることができる。すなわち，フェアウェイから遠ざかる につれ，段階的にラフの刚高を高くしていくことが可能である。
また，現状で刚高が $15 \mathrm{~mm}$ であるフェアェイについても，刚 高を $20 \mathrm{~mm}$ 程度に変更することで, 㺫り芝残さの発生量を増加さ せることができると考えられる。フェアウェイの刚高では， $15 \mathrm{~mm}$ よりも $20 \mathrm{~mm}$ の方が明らかに雑草の発生が少ないことが確認され ており ${ }^{10)}$, 除草剤の施薬量の減少にもつながる。施薬量の削減は, 除草剂の製造や運搬に使用される化石エネルギーを節減すること から, 間接的な二酸化炭素の排出量削減効果む期待される。

\section{7. 里山ゴルフ場におけるバイオマスエネルギーの活用に向けて}

里山ゴルフ場では，連日の芝地管理から発生する刈り芝残さに 加え, 樹木剪定や樹林地管理から, 落ち葉や剪定枝類などが不定 期に回収されている。樹林地管理から発生する植物性廃棄物は, 生物相の保全に向けた二次林の維持管理 ${ }^{3}$ から, 将来さらに増加 する可能性むある。ただし，不定期に回収されるバイオマスは， そのままでは処理設備の導入や利用システムの構築が困難であり， 計画的な利活用を抗こなうことはむずかしい。しかし，そうした バイオマスについても，日常的な刚り芝残さのバイオマス利用に 組み込むことで，実際の利用に結びつけることができると考えら れる。また，樹木剪定や樹林地管理から回収されるバイオマスは 里山管理に共通するあのである。バイオマス利用の実例を里山ゴ ルフ場で先駆的に示すことにより，里山でのバイオマス利用を検 討する際の足がかりを築くことができる。

\section{8. 今後の課題}

本研究では, 実際の刚り芝バイオマスのエネルギー活用におけ る採算性についてまでは言及することができなかった。初期設備, 運搬，処理などの刚り芝バイオマス利用にかかるコストや，無料 の原料から得られる代替エネルギーなどの利益を試算し，実用に 向けて，さらに検討を加えていく必要があると考える。

\section{謝辞}

本研究は, 日本生命財団研究助成による「里地自然保全戦略の 構築」の一環として奏施された。音産草地研究所の鶴見義朗氏お よび中川仁氏，明治大学の舆水肇教授，産業技術総合研究所の横 山伸也氏, 千葉県農業総合研究センターの真行寺孝氏には貴重な アドバイスを頂いた。A ゴルフ場の関係者各位, 滑川町の木村俊 彦氏および松本由紀夫氏には多大なる協力を頂いた。この場を借 りて感謝の意を表し，厚く御礼を申しあげたい。

\section{参考文献}

1）横山伸也（2001）：バイオエネルギー最前線： 森北出版, $167 \mathrm{pp}$

2 ）環境省 地球温暖化防止のための税の在り方 検討会（2001）：地球温暖化防止のための税 の論点報告書, $122 \mathrm{pp}$

3 ) 栗田英治・横張真 (2001) : 里山ランドスケー プの保全に果たすゴルフ場の役割とその管 理手法：ランドスケープ研究 64(5), $589-$ 594

4 ）藤崎健一郎 (2001)：外観的生育状態（地上 部, 地下部) の調查, 日本芝草学会編, 最新 芝生・芝草調査法：ソフトサイエンス社。 396pp. 46-57 に所収

5 ）北村文雄 - 眞木芳助・柳久 - 大久保昌 - 野 間豊（1997）：芝草・芝地ハンドブック：博 友社, $348 \mathrm{pp}$

6) Sakai, M. and Kaneko M. (1996) : Bioma ss Fuel for the 21st Century : Proceedings of MAFF International Workshop on Versatile Use of Agricultural Products, 13-22

7) Nakagawa, H., M. Sakai, T. Harada, Y. Kitamura, K. Taniwaki, and A. Hashimoto (2000) : Biomethanol Production and $\mathrm{CO} 2$ Emission Red uction from Various Forms of Biomass : Proceedings of the 4th International Conference on EcoBalance, 405-408

8 ）吉田重方・堀達雄（2000）：刈取り芝草残さ の分解特性とコンポス卜化に関する基礎的 研究：資源環境対策 36(1)，81-86

9 ) 田中雅・小倉義己・杉浦恒彦 (1996) : 電子 ビームによる排䙳処理技術の開発：火力原 子力発電 $47(12), 77-83$

10）千葉県農業試験場 (1999)：芝草の無農薬管 理に関する研究(中間報告), $344 \mathrm{pp}$

Summary : Summary : It is worth utilizing the plant waste from plant management in hilly areas as a bio-energy source in the reduction of $\mathrm{CO}_{2}$ emissions. This study looks at the turf management of golf courses in hilly areas. The biomass of mown turfgrass was analyzed for five turf species in a studied golf course located in the Northern Hiki hill region in the center of Saitama prefecture from July 2000 to September 2001. 299 samples were collected and the vegetative production from the turf management was estimated at $398 \mathrm{~g} / \mathrm{m} 2$ per year. It was also estimated that $175 \mathrm{~g}$ of bio-methanol could be produced from the $398 \mathrm{~g}$. of mown turfgrass by a method of gasification. Eco-management schemes for golf courses were discussed with a view to utilizing bio-energy by referring to the vegetative production. Effective management schemes consist of increasing the collected amount of mown turfgrass and increasing the mowing height to promote the growth of turfgrass. 